\title{
Cyclin-Dependent Kinase Inhibitor
}

National Cancer Institute

\section{Source}

National Cancer Institute. Cyclin-Dependent Kinase Inhibitor. NCI Thesaurus. Code C2185.

Any substance that inhibits cyclin-dependent kinase (CDK), an enzyme that catalyzes the addition of a phosphate group to a protein in the cell cycle regulation pathway. Inhibition of cyclin-dependent kinase results in cell cycle arrest and apoptosis. 